\title{
DECOMPOSITION AS LIFE POLITICS: Soils, Selva, and Small Farmers under the Gun of the U.S.-Colombian War on Drugs
}

\author{
KRISTINA LYONS \\ University of California, Santa Cruz \\ (D) http://orcid.org/0000-0003-2832-9425
}

Having momentarily broken away from the group, I stood, waiting in silence, between rows of climbing plants, fruit trees, beds of tubers, and shrubs. The sunflowers by my side leaned forward only slightly. A nearly imperceptible breeze caused the vines to quiver. The scent of rotting fruit rinds rose up from the ground. There was a distant flap of wings. Much closer, I could hear larvae chewing on the granadilla leaves and insects humming from within knotty bundles and flower petals. It was cooler here, and the humming grew more intense. My only words for it, a hundred damp index fingers gliding around the rims of water glasses. Life as it pulsates, withers, draws at once a next and last breath. This was the distinct sound - better yet, force-permeating the air when I first stepped off the bus in San Miguel, Putumayo, at the Amazonian farm school La Hojarasca, which means "litter layer" or, more colloquially, decomposing leaves often used as compost. Groups of farmers were conversing next to a wooden table lined with seeds as big as fists, others as tiny as mites. Hens and wild turkeys roamed about trampling through the underbrush. A family of geese honked noisily as they descended on their lunch of minced sugarcane. There was the crunch of boots pressing down on layers of decaying leaves and stalks, a sound quite distinct from the squish of shoes sliding against bare mud. I heard the slice of a machete, the heavy thump of copoazu when the fruit hit the ground, laughter, buzzing, and the friction of scraped stone as bore leaves were ground into grain. The trees were lined with mochilero nests, and every so often I could make out the birds' call - the sound of water, the reverberation of a drop of water, that almost-electric sound it makes in the 
exact moment it hits a surface and morphs into disparate forms. I failed to sense Heraldo's presence until I heard a voice call out from behind. "Wouldn't you agree," he asked as he approached where I stood in the middle of the creeping plant garden, "life makes life happier?"

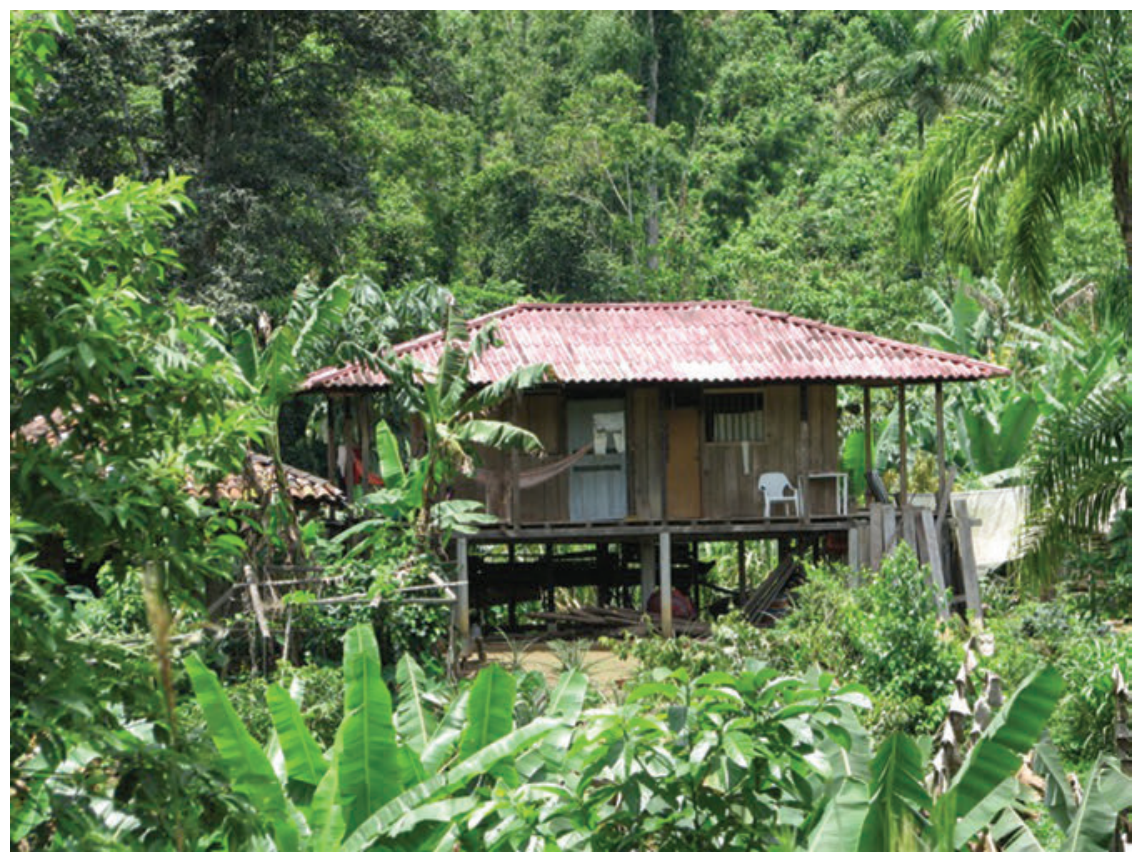

Figure 1. A small farm in the Andean-Amazonian foothills of Colombia. Photo by Kristina Lyons.

From April 2008 to March 2011, and again between June 2013 and April 2014, I conducted fieldwork in and around the southwestern frontier state of Putumayo among small farming families, rural social movements, soil scientists, state officials, armed actors, and aid workers. Referred to as the gateway to Colombia's Amazon, Putumayo shares borders with Ecuador and Peru, and transitions from central Andean foothills into the extensive Amazonian plains that comprise 85 percent of its territory. With 66,022 hectares of commercial coca under cultivation in 2000, the year the bilateral U.S.-Colombian antinarcotics policy Plan Colombia commenced, Putumayo produced around 40 percent of the nation's illicit coca (UNODC 2005). The region quickly became the focus of militarized eradication, as well as state and U.S. Agency for International Development (USAID) crop-substitution efforts. The global militarization of the drug 
war in the 1980s became more explicitly intertwined after 9/11, with the hemispheric conflation of counternarcotic and counterterrorism wars. This merger resulted in a series of military surges into southern Colombia, where the oldest and largest leftist guerilla group in the country - the Revolutionary Armed Forces of Colombia (FARC-EP) — and right-wing paramilitary groups operating with the complicity of state military and police forces had battled over territory and control of the cocaine trade since the 1980s. After the official demobilization in 2006 of the umbrella paramilitary organization, the United Self-Defense Forces of Colombia (AUC), paramilitaries are said to no longer exist. ${ }^{1}$ Yet overwhelming evidence suggests that mid-level commanders failed to demobilize or simply reorganized into countrywide narcocriminal structures, such as Los Rastrojos, Los Urabeños, or Los Constructores, which continue to operate in Putumayo. The Colombian government now refers to these groups as bacrim (emergent criminal bands).

Since 2000, Plan Colombia has provided around $\$ 9$ billion in supply-side drug interdiction assistance. As much as 75 percent of aid has been invested in provisioning weapons, equipment, technical assistance, and training for Colombian military and police through contracts with U.S.-based multinationals like Monsanto, Sikorsky Aircraft, and Dyncorp International (Beittel 2012). For twenty years, forced eradication strategies relied on a controversial aerial fumigation program that remains a heated topic of science wars disputing its environmental and public health risks. The program consisted in deploying crop-duster planes to spray a concentrated formula of Monsanto's herbicide glyphosate over suspected illicit crops. ${ }^{2}$ Aerial aspersion operations were coupled with manual eradication by contracted workers who were sent, accompanied by the military and police, to rip out whatever stubborn coca plants remained after crop dusters passed overhead. In Putumayo alone, 277,849 hectares have been aerially fumigated since 2000, and 82,780 hectares of coca have been manually eradicated since 2004. ${ }^{3}$ Despite this, Putumayo continues to produce 20 percent of the country's illicit coca, exemplifying long-standing critiques of the effectiveness of repressive eradication strategies in achieving permanent national reductions in illicit crops (UNODC 2015). A long-awaited resolution to suspend aerial fumigation with glyphosate was issued by the Colombian government on May 29, 2015, in the wake of a report published by the World Health Organization's cancer research arm declaring the world's most widely used herbicide a probable carcinogen to humans. It is still unclear what policy will come to replace aerial spraying after the National Environmental Licensing Agency (ANLA) suspended the license to use glyphosate in aerial fumigation operations on October 1, 2015. 
Colombia, up until that point, was the only country in the world to implement aerial fumigation as a counternarcotic strategy.

I began fieldwork in the Andean-Amazonian foothills in 2004, at the height of renewed critiques of Plan Colombia. Through the ensuing years, as I returned to Putumayo for further research, to film a popular education project, and to accompany farmers during the 2013 National Agrarian, Ethnic, and Popular Strike, I was struck not so much by the kinds of violence and ecological destruction produced by the War on Drugs, but rather by the tenacious vitality of life in the midst of war. Indeed, what most impacted me when I first arrived at La Hojarasca in 2007 was the pulsation the farm school was generating, literally resonating by its very existence in the midst of a criminalized ecology. It was bundles of life pulsating away _ dense entanglements of diverse plants, decomposing leaves and rootlets, the buzz of insects, the sounds of small animals and birds cloaked by selva canopy - that allowed it to carve out a transformative space for itself, even if precariously so. This was not a space where life was simply enduring within social suffering and contamination, but rather one where other modes of eating, growing, seeing, exchanging, cultivating, and hence, decomposing were being set in motion - what the farmers I met refer to as selva or agricultura amázonica (Amazonian agriculture). While selva is often translated into English as "jungle"a word imbued with a complex colonial history and civilizatory connotations - I continue to use the Spanish word selva throughout this article, because I learned from farmers to treat selva as a concept, analytic, and relation, rather than as an entity that can easily be divided into units or reduced to a representational landscape descriptor. Furthermore, these farmers explained that the word forest does not necessarily convey biodiversity, since it may refer to a monocrop or arrangements of commercial timber. Indeed, my research questions and political commitments were deeply impacted by this pulsating farm, La Hojarasca, and I set out to explore the contrasting logics of life and death, the kinds of possibilities and foreclosures for both living and dying, in a tropical forest ecology under military duress. What I learned was that rather than on productivity-one of the central elements of modern capitalist growth - the regenerative potential of these ecologies relies on organic decay, impermanence, decomposition, and even a robust fragility that complicates modernist bifurcations of living and dying. This allows, I argue, for ecological imaginaries and life processes that do not depend on productivity or growth to strive into existence. 


\section{PEACE THROUGH POISON}

"The general did not mince words. He said it like this: 'The only solution is to arm yourself, leave, die, or figure something out.'”

— Small farmer, Piñuña Blanco, Putumayo, August 2013

At times I heard farmers in Putumayo speculate that not only herbicides but also biological weapons had been released in covert experiments to attack coca crops. They described swarms of black butterflies descending on fields, and a pathogenic fungus - Fusarium oxysporum - infecting forest floors. ${ }^{4}$ However, the butterflies' larval offspring seemed to munch on just about anything besides coca leaves, and suspiciously mirrored the way spray-drift from aerial fumigation most often kills staple foods, pasture grass, forest canopy, and even USAID alternative development crops rather than targeted illicit plants. Furthermore, alternative development programs have tended to follow the same market logic of commercial coca, largely failing to substitute illicit export-oriented crops with legal market-oriented varieties, such as pepper, coffee, vanilla, heart of palm, and cacao. ${ }^{5}$ I clearly remember the day I accompanied a farmer as she pointed to a row of dying cacao plants that were part of a USAID crop substitution pact that local communities had signed, and that had been fumigated two weeks earlier. "There is no way to say this," the woman told me. We stood for a long while in her field in silence. A group of indignant neighbors gathered near the front of the house displaying deformed plantains, wilted husks, and more cacao and pepper leaves riddled with holes and spots. Others expressed growing uncertainties about the protracted life span of chemical agents in human bodies, soils, and watersheds. Antidrug policy "está acabando con la vida [is finishing off life]," they said. Toxicity seemed likely. One waited to be deprived of the resources that allow living beings to thrive - at any moment the sting of a droplet, a dampened leaf, inhibited enzyme, and the end to synthesis - a strangling of life from the inside out. It was not lost on this woman or any of her neighbors that their life staple had been excised so that life elsewhere, and in the wounded soil itself, could claim to be protected and flourish.

Cocaleros (coca growers) have argued since the first massive coca growers' protests in southwestern Colombia in 1996 that repressive antidrug policy produces a cocriminalization of "natures" and "subjects" — plants and people (Ramírez 2001). A criminalized nature is no longer the object of conservation or protection, and is perceived to be in cahoots with a criminal subject rendered ineligible for humanitarian aid even when public policies turn people into internally displaced 
populations and refugees. On the one hand, the Colombian government has been willing to aerially fumigate its national parks and the biodiverse Amazon Basin. On the other, Law 30, passed in 1986, criminalizes the cultivation of marijuana, coca, and opium poppies in excess of twenty plants. This places small growers, who account for around 70 percent of coca cultivation (UNODC 2005), and large-scale traffickers in the same legal category by ignoring the structural forces that lead individuals and families to settle in rural frontier zones and resort to illicit livelihoods in the first place.

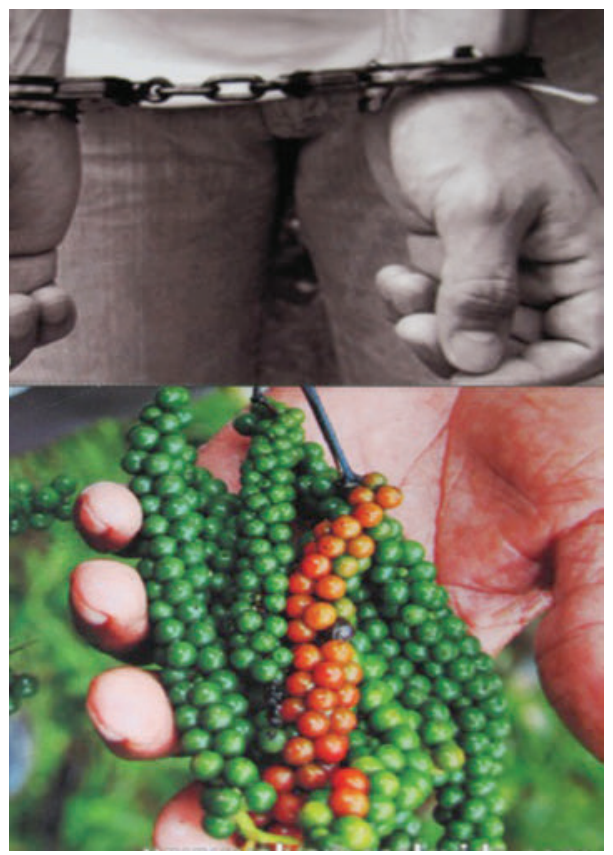

Figure 2. USAID postcard distributed during the 2009 Volvamos a la Vida campaign.

It is a liberal way of making and justifying the ongoing nature of war that wraps various kinds of killing within an imaginary of safeguarding and life-making narratives. Killing is posed within a "future perfect" tense (Povinelli 2011a, 167) as a necessary redemptive mode of birth that will bring new beings and domains of social life - in this case, the geopolitical intervention of liberal moralities, such as rule of law, culture of legality, public health, and licit capitalist-based economies - into existence. The capacity to make live rests on the necessity to make die, rendered evident in the dual meanings of the Colombian Spanish word arrancar (as in arrancar la coca). Arrancar means to start something - an engine, for 
example - and also to uproot or rip out, a violent cleansing or weeding out that pries open the space for regrowth. A 2009 Volvamos a la Vida (Back to Life) campaign organized by USAID in Putumayo posed what one government official called "reflective questions about the social drawbacks of cultivating illicit crops." Postcards distributed during the campaign starkly contrasted black-and-white images with images in color. They read: "Live or die? Smile or cry? What kind of life are we sowing?" and pose a moral choice between pepper harvests or handcuffs, saxophones or headstones, goalie kicks or toes tagged in a morgue. La mata que mata (the plant that kills, according to stigmatizing state campaigns) must be purged from soils and souls. A disavowal of criminal mentalities - crime blamed on a primitive form of individual propensity — becomes necessary for cocaleros' resuscitation not only back into the nation's productive citizenry but also back to what state and USAID officials sanction as a better and more dignified life than the social and literal death supposedly produced by an illicit livelihood.

At first glance, it seems possible to situate the chemical warfare and overall eradication component of antidrug policy within other biopolitical histories and formations of killing: in this case, one in which a future peace is actively pursued through present acts of poisoning. ${ }^{6}$ However, at stake at the heart of antidrug policy is not only the taking of the biological life of a plant or the severing of illicit human-plant relations in the defense of security, territory, and population in the context of international pressures to wage a war against narcotic drugs. Rather, it is the increasingly evident association between eradication efforts and the expansion of a national development model euphemistically referred to as a locomotora minero-energética, which I roughly translate as "mining-energy locomotive” (Departamento Nacional de Planeación 2010). In 2011, more than half of Putumayo, along with several neighboring regions, was reclassified from Amazonian territory to Special Mining District, accelerating oil production from 8,000 barrels a day in 2000 to 48,000 in 2013 (Calle 2014). The biodiverse ecosystems of the Andean-Amazonian foothills have never been conceived of as anything other than a commodity frontier, beginning in the nineteenth century with the voracious extraction of quinine, rubber, and timber, and followed in the twentieth century by intensified oil exploitation and the boom-and-bust waves of monoculture coca (Aguilar 1999; Taussig 1984). These extractive activities violently dispossessed native indigenous populations and propelled the modern colonization of the region, as well as the sporadic extension of the nation's agricultural frontier. Waves of small farmers, urban dwellers, and indigenous peoples not originary to the western Amazon were driven to occupy the territory due to land concentration 
in the country's Andean interior, increasing urban poverty and ongoing political violence since the 1940s (Ariza, Ramírez, and Vega 1998). ${ }^{7}$

The prevailing analysis among rural communities living in coca-growing regions is that antidrug policy has allowed for an intensified and qualitatively different mode of transnational capitalist expansion, linking the role of foreign direct investment in war through the securitization of development. Antidrug policy has become a pretext not only to wage a war against the people (guerra contra los pueblos) (Paley 2014) but also to wage a war against life (guerra contra la vida). Or, similarly, a war waged in defense of growth at the expense of all forms of life. In the process, a variety of social values become reduced to one exchange value, and a diversity of ecologies, ethics, and practices said to produce death in life (that is, illicit coca cultivation), or that cannot be assimilated to or openly resist growth-oriented and extractive-based priorities, are actively dismissed or rendered impossible. Indeed, rural communities in Putumayo perceive militarized aerial fumigation as yet another violent attempt to weaken their will: one mode of destroying the material base and food crops of local sustenance, starving them out in an effort to force the abandonment of territory that facilitates industrial oil and mining concessions. Moreover, Colombia's Law 160, passed in 1997, prohibits the titling of land within a five-kilometer radius of oil or mining exploitation. Small farmers argue that this law contributes to the ongoing concentration of land and the precarity of property titles in a country that has never undergone a lasting history of agrarian reform. ${ }^{8}$

It is life, and not only human rights or land rights, that has come to the fore in rural struggles against extractivism, GMO seeds, biofuels, and other forms of industrialized agriculture, large-scale infrastructural projects, free-trade agreements, and all sorts of neoliberal reforms privatizing public goods and services and fomenting transnational capitalist growth throughout the hemisphere. Of course, development has always signaled more than just material progress and economic growth indicators: it has marked a historically specific model of judgment and control over life itself. Although modern capitalist principles such as growth, progress, better living, and their correlate-more development - have been thoroughly repudiated in theoretical debates emerging in the global South since the mid-twentieth century, these principles remain politically and economically dominant (Escobar 2011, 2014). A new set of struggles over the definitions of and relations between nature and resources has become one of the most salient features of contemporary Latin American political dynamics in both overtly neoliberal regimes and in self-declared post-neoliberal ones. Economic 
convergence around a growth-oriented development model-mostly a wave of neoextractivism — can be witnessed across ideologically opposed progressive leftist and conservative governments (Gudynas 2014; Veltmeyer and Petras 2014; Bebbington and Bury 2013). It becomes crucial, therefore, to ask: What kinds of radical politics or structural transformations can exist if socioenvironmental justice and sociopolitical inclusion tend to be fueled through the same modern, capitalistbased model of extraction? Indeed, what relations to life and death, place and territory will be potentiated and which others will continue to be criminalized, rendered obsolete, or sacrificed in the name of national growth and social(ist) good? These questions lie at the heart of Colombia's ongoing national peace process between FARC-EP guerrillas and the state as the country continues to debate its socioeconomic-environmental future, including the terms of a democratic reformulation of antidrug policy and integral agrarian reform in a possible post-conflict scenario of transitional justice. ${ }^{9}$

\section{THE CULTIVATION OF COUNTERLIFE AND DEATH}

Rather than ask what it means for rural communities to live in coca-growing regions that have been epicenters of Colombia's violence, I follow the practices that make life possible in a criminalized and poisoned ecology. How do people keep on cultivating a garden, caring for forest, or growing food when at any moment a crop-duster plane may pass overhead, dousing entire landscapes with herbicides? Beyond official policy imperatives to "uproot (coca) or be uprooted"extract or be extracted from — what other potentialities and limits emerge among communities that are responding to war by cultivating life, which is not altogether separate from death? I came to these research questions from a shared conceptual ground built through my long-term relationships with a dispersed network of farmers whom I first met at La Hojarasca. These farmers did not tell me stories of social suffering and abandonment or the endurance against all odds of precarious life (Nouvet 2014; Allison 2013; Das 2006; Biehl 2005). Nor did they dwell on modern life rendered meaningful only by denouncing its finitude, and thus animating biopolitical logics that aim to optimize, regulate, and police all sorts of transgressors against proper human ways of living and dying (Stevenson 2014; Zeiderman 2013). Instead, they obliged me to depart from a biopolitical register that distinguishes between life and death, and between human life and the wellbeing of other entities to make an ethico-analytical move and pay careful attention to processes of human and nonhuman material composition and decomposition. The farmers did not describe a romantic relationship with the selva, but rather 
what and how they were learning from the recycling nature of hojarasca - rot, decay, and regeneration - which emerges along with the cultivation of experimental practices on farms and forests in the midst of war. The agrarian-based material practices and corresponding life philosophies they shared open up ways of thinking about the different kinds of political, economic, and ecological relationalities that emerge when life and death are no longer (or never could be) experienced as oppositional categories or morally dictated ultimates.

My work is influenced by scholarship at the interface of anthropology and feminist science studies that critically bypasses a modern nature/culture divide and a cascade of associated distinctions (such as objects/subjects, bio/geo, and organic/inorganic) to arrive at processual understandings of life that necessarily reconceive our notions of the human, and consequently of politics and ethics (Tsing 2011; de la Cadena 2010; Stengers 2010; Haraway 2008; Mol 2008; Barad 2007; Verran 2002). However, rather than concentrate on realized things or achieved political events, which has been the focus of much of the twentieth century's and, especially, the international left's political thinking, I build on scholarship that emphasizes everyday transformations in the ways people produce, reproduce, consume, and hence compost their material worlds (Puig de la Bellacasa 2013; Papadopoulos, Stephenson, and Tsianos 2008; Gibson-Graham 2006). In particular, I focus on what these processes of decomposition and renewal may tell us about the everyday practices through which not only people but entire ecologies - trees, soils, plants, seeds, insects, chickens, microbes, and farmersstrive to collectively change the conditions of their lives. They do so not by transcending these conditions, but rather by sinking into them, slowly turning them over, aerating, and breathing in new life that also potentiates different possibilities for and relations to death.

I draw on Elizabeth Povinelli's (2011a, 2011b, 2011c; Povinelli and Berlant 2014) and Kathleen Stewart's (2007) discussions of potentiality to open up ways of thinking about how alternative life processes — always at risk of disappearing and with no guarantees - come to shake loose, to whatever degree possible, from dominant definitions to set something else in motion. Not in the sense of denouncing the world in the name of an ideal world, or in the rush to push aside one set of object and subject positionalities to replace it with another, but rather in the ways that bodies, dreams, and socioecological relations of all kinds strive to pick up density and texture without necessarily being rooted in fixed conditions of possibility. I depart from Povinelli's work in that I am interested not only in potentiality but also in the actualizations germinating in the very thickness of the 
present. The creative emergences and actual work occurring in the present when cultivating different conditions for life and death also constitute a contestatory act motivated by what farmers in Putumayo describe as "propositional rage" (Mesa Regional de Organizaciones Sociales 2015). Propositional rage not only opposes or denounces current social conditions but also works to cultivate alternatives to the asymmetric forces that make certain ecologies thrive at the expense of forcing others to endure.

It was a dispersed group of farmers in Putumayo, including my closest farmer friend and intellectual colleague, Heraldo Vallejo, who rejected commercial coca since its arrival in the region in 1977, even though they respect coca leaves as medicine, sustenance, spiritual substance, and a constitutive element of local biodiversity. These farmers argue that both monoculture coca and its official alternatives force not only people, but all the life forms with whom they live and labor, into dependent relations with market-based goods, modes of exchange, and values. They critique this singular economic logic, in part, because it treats commodity exchange as a founding principle of agrosociality, assuming that small farmers are simply poor farmers lacking the proper technology, financial capital, alliances, and work ethic to become full-blown agroindustrial farmers. This kind of economic model dismisses small farming as an obsolete livelihood of the past. It has also turned Putumayo into a laboratory for public policies gone awry by denying the cultural particularities of small farming families and economies, as well as the ecological conditions of a particular Amazonian territory. Heraldo is an animal husbandry technician, and one of two students from his rural elementary school who finished high school and went on to study at the closest university in the neighboring Andean state of Nariño. Following graduation and imprisonment as a leftist student leader, he returned to Putumayo to, as he says, "unlearn" the dominant teachings of agricultural science. He uses the term agricultura de la muerte (agriculture of death) to refer to the extractive-based practices that result when farmers begin to perceive themselves as external to, rather than conforming relations within Andean-Amazonian ecologies. Concretely, agriculture of death refers to the use of chemical inputs, patented and transgenic seeds, monoculture and export-oriented crops, land-titling premised on deforestation, a singular notion of the market, and neoliberal reforms implemented during the past two decades all of which strangle and attempt to render obsolete diverse small-farming practices and economies. ${ }^{10}$

For two years, I spent at least part of every day accompanying Heraldo and other farmers as they worked on their farms to turn them into collective spaces 
of aprendizaje e intercambio (learning and exchange). They conceive of their farms as spaces of learning rather than knowing, and contrasted them with the model farms that form part of conventional state agricultural extension. Rather than teach standardized technical models intended to be replicated from one farm to the next, these farmers strive to multiply biodiversity across farms by engaging in the production of what Heraldo calls conocimiento vivo (live or living knowledge). Living knowledge results from ongoing experimental processes in gardens, orchards, and forests precisely because seeds, soils, plants, and trees become entities through recursive relationalities that are always in the making, awaiting their next realization based on different socioecological conditions, human aptitudes, and imaginaries. Given the historic lack of agroecologically appropriate state-based technical assistance, the decades of breached political agreements on the part of the national government after previous civilian protests and mobilizations, and the ways both monocrop coca and repressive antidrug policy have largely eliminated local food production, these farmers have come to provide an informal regional network of alternative agricultural technical assistance. Thus I also joined them when they worked in solidarity with small-farming associations, unions, and indigenous communities interested in gradually transitioning from commercial coca, USAID development models, and other unsustainable agricultural systems to what they refer to as selva or Amazonian practices. This included attending popular education workshops with the Regional Working Group of Social Organizations of Putumayo, Baja Bota Caucana, and Cofanía, Jardines de Sucumbíos Nariño; Inga and Nasa indigenous reservations; guardians of seeds networks; and rural communities that form part of the environmental clinic in neighboring Sucumbíos, Ecuador. ${ }^{11}$ My fieldwork also led me to collaborate with the Regional Working Group of Social Organizations in the design of an Andean-Amazonian Integral Development Plan (PLADIA). This plan aspires to provide a communitydesigned alternative to official rural development paradigms, and to address the structural conditions that lead to illicit coca production and the displacement and impoverishment of rural families in the region. ${ }^{12}$

The mere existence of these selva practices in gardens, orchards, and forests brings something into being. They express the capacious potential for life to strive to resist the polarizing and irreconcilable terms of life and death embedded in public policy. However, Amazonian or selva agricultural practices are not yet widespread beyond a dispersed network of small farming families. Alternative agricultural proposals form part of an ongoing twenty-year political struggle between the state and regional social movements as the latter oppose antidrug policy 
and extractive economic development, and reimagine how to build a different political, economic, and socioenvironmental future for the territory. The Amazonian-based agricultural practices I witnessed are a central component in the design of what PLADIA calls a transition to fincas agroproductivas sostenibles (sustainable agroproductive farms).

Inspired by what I came to think of as pulsations of cosustainability - these dispersed selva practices striving to resonate and multiply across the AndeanAmazonian foothills outside existing modes of agrarian regulation - I now focus on one family that forms part of this alternative agricultural network. What most compelled me is their everyday cultivated partnership with soils, and in particular, how this partnership enabled a sundry of organisms and elements, including humans, to resist violent modes of death by becoming into death rather than working against it in the pursuit of a better life. By becoming into death, I refer to a mode of dying that is an aspect of the transformation of being, an emerging into many other living and dying things much like the regenerative decay of hojarasca or decomposing leaves. This kind of death results from the recycling of selva life rather than the violence of war, or, what is the same, killing in the defense of growth.

The story of the family's forced return to Mocoa pivoted on a negotiated displacement between Don Nelso and members of the AUC who forcibly occupied the subregion known as Bajo Putumayo in 1998, where the majority of coca in Putumayo is still grown. The paramilitaries explained that they had no real reason to chase Nelso out of town, as they had been watching him for months and found no evidence that he was collaborating with FARC guerrillas. However, other people wanted him gone, and these families made use of a generalized context of violent displacement to wage personal vendettas. ${ }^{13}$ Nelso had acquired enemies as a community leader encouraging cocaleros to stop cultivating the crop before the state's threat of aerial fumigation honed in on the region. This was 2001, and visible seesaw trajectories between town and country drew immediate suspicion due to the strict territorial divide imposed by the FARC and the paramilitaries as they vied for control over land, local populations, coca production, and the cocaine trade. The death threat that paramilitaries nailed to Nelso's front door read: "WE WILL MOW YOU DOWN WHILE YOU WALK HOME!" Paramilitary violence was most gruesome in the dismembering of bodies and the public throwing of corpses into nearby rivers, a kind of ultimate deterritorialization of bodies from soils and souls. It was a quick decision. Nelso and his wife, María 
Elva, packed up a few belongings and headed north with their five children until they reached Putumayo's capital town of Mocoa.

What followed was a year, as they described it, of quedándonos quietos (lying low; staying still), a forced retreat from public life and the exposure inherent in too many social relations. They were lucky enough to receive a government housing subsidy for displaced families, but when the first opportunity arose, they traded the one-room apartment for half a hectare of land on the outskirts of Mocoa. The family has not yet been able to formalize the land title, and a handwritten note continues to serve as a deed. "We were getting sick living in a matchbox," Elva tells me. She is bent over a cafeteria tray full of seeds, varieties of beans we inspect for tiny holes, a literal worming-in of uninvited mouths. These are "beans for eating, not for commercial purposes," Nelso explains, but of course, not all mouths are the same, nor are they fed equally. These are beans to feed other beans, beans to feed microorganisms and cloak naked soils, to gift and trade; they are also for the family's lunch and dinner. Red, black, speckled, gray, maroon, shades of café and mustard. Not only seeds, then, but mouths as well. One by one these seed-mouths are turned over in the palms of hands and stored again, a laborious practice to cleanse rather than submerge them in chemical insecticides.

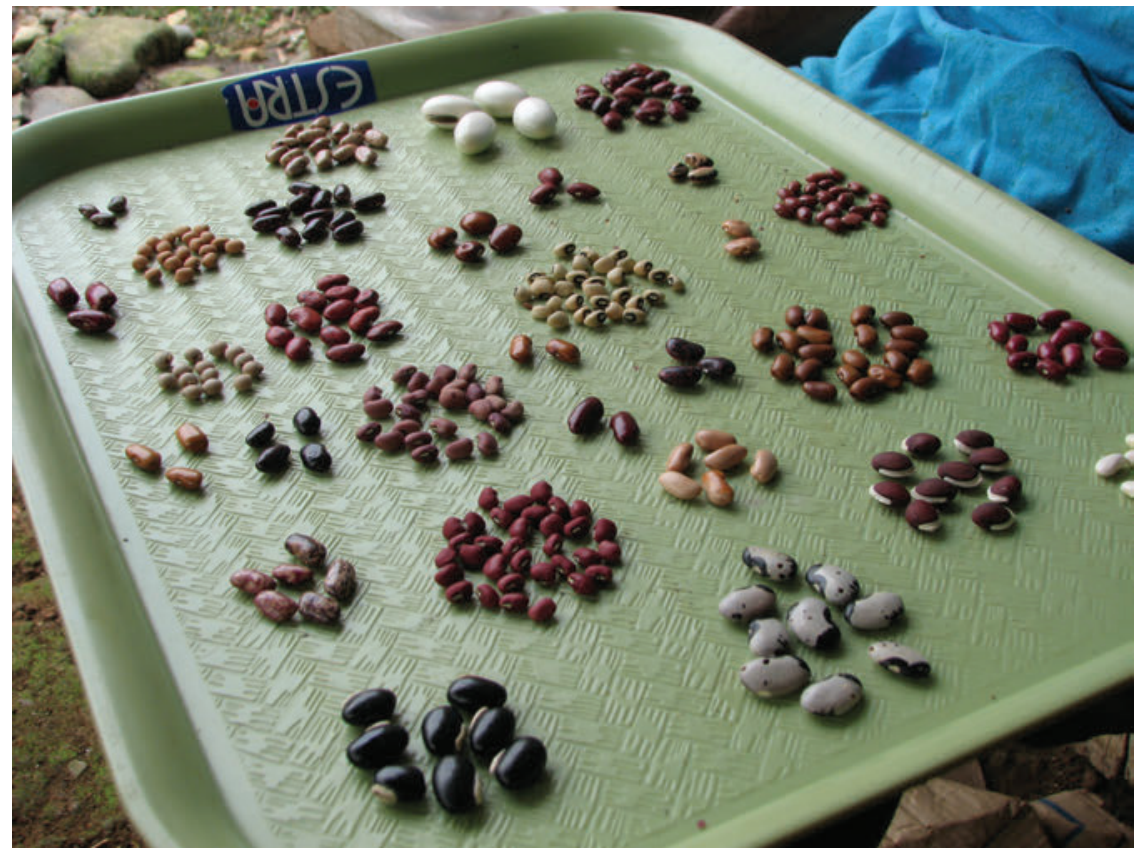

Figure 3. Thirty varieties of beans grown in Nelso and Elva's garden. Photo by Kristina Lyons. 
Glancing over at their neighbor's plot, I begin to envision what the area looked like more than ten years ago when they first arrived. A stretch of rust-colored earth, compacted by hooves, burned out by herbicides, open faced and exhausted. "Seemingly left for dead," says Nelso, referring to a state of being which, as I explain later, can be conceived as refusal - a state of imperceptible playing-dead through which regenerative transformation may be achieved. In the case of their neighbors, like so many farmers following the Green Revolution technical advice of agronomists advocating for the use of chemical inputs - and to whom Nelso refers as ladrónomos (or "thiefgronomists") - the natural limitations of Amazonian soils have to be continuously struggled against and corrected. ${ }^{14}$ Nelso's punning neologism for the agronomists speaks to the softer kinds of violence exerted through dominant technoscientific paradigms, and to how small farmers find their knowledges, ethics, and practices under the gun of capitalist productive imperatives. To combat the so-called poverty of the soils - their thinness, acidity, old age, and mineral deficiency-Nelso describes the conventionally prescribed technical treatment plan: drips of urea and Triple 15, a chemical pump strapped to the back of a farmer, the hissing sound it makes close to an ear like an old man's raspy breath. An entire life-support system is assembled not only to resuscitate the soil but also to force its betterment. It is treated not as a natural body with corporeal finitude, but rather as artificial strata whose mortality is not only cast as a weakness to be overcome but is all but denied.

In stark contrast to this kind of optimization of the soil's regenerative capacities, Doña Elva spoke about "creating conditions." These conditions do not forcibly supersede corporeal vulnerability to resuscitate soils, but allow for the kind of withdrawal that the family sees its own lives cyclically retreating into and slowly emerging back from: underemployment, displacement, landlessness, lying low, and the ongoingness of recovery. They were not in the business of imposing conditions to make productive soils or -in a broader sense-productive lives emerge. Rather, each day Nelso and Elva bring together seeds, manure, eggshells, husks, and vegetable and fruit skins to create conditions for their intermingling in anticipation of what might emerge. An example is the way decomposing bodies and elements - litter layer, ash, rinds, rootlet, manure, human urine, sugarcane mashcome to mutually constitute each other as they transform into hojarasca, which holds their traces while also constituting something new.

Nelso and Elva began by collecting the cans, tires, and plastic bags left behind by previous residents. They discussed which plants would be their allies in interrupting the life cycles of the domineering pasture grasses that flourish in open sunlight. They planted sunflowers, low-growing kisses, yams, beans, cowitch, cudzú shrubs, and wild clover: food and protective covering for others, mostly microbes that would nurture plant rootlets that would eventually come to shade soil. Then they waited, thinking, searching for building 
materials to "create conditions" for the house itself. In this way their shared lives-soils, farmers, plants, worms, microbes - emerged out of a retreat as necessary as it was imposed. Many neighbors and agricultural extension experts looked on in bewilderment as they watched them sow what appeared to be roadside weeds. "Los locos viviendo en medio del rastrojo," they said - crazy people living in the midst of animal fodder, or the selva that returns when left unattended, and that most farmers clear in the act of occupying and working the land.

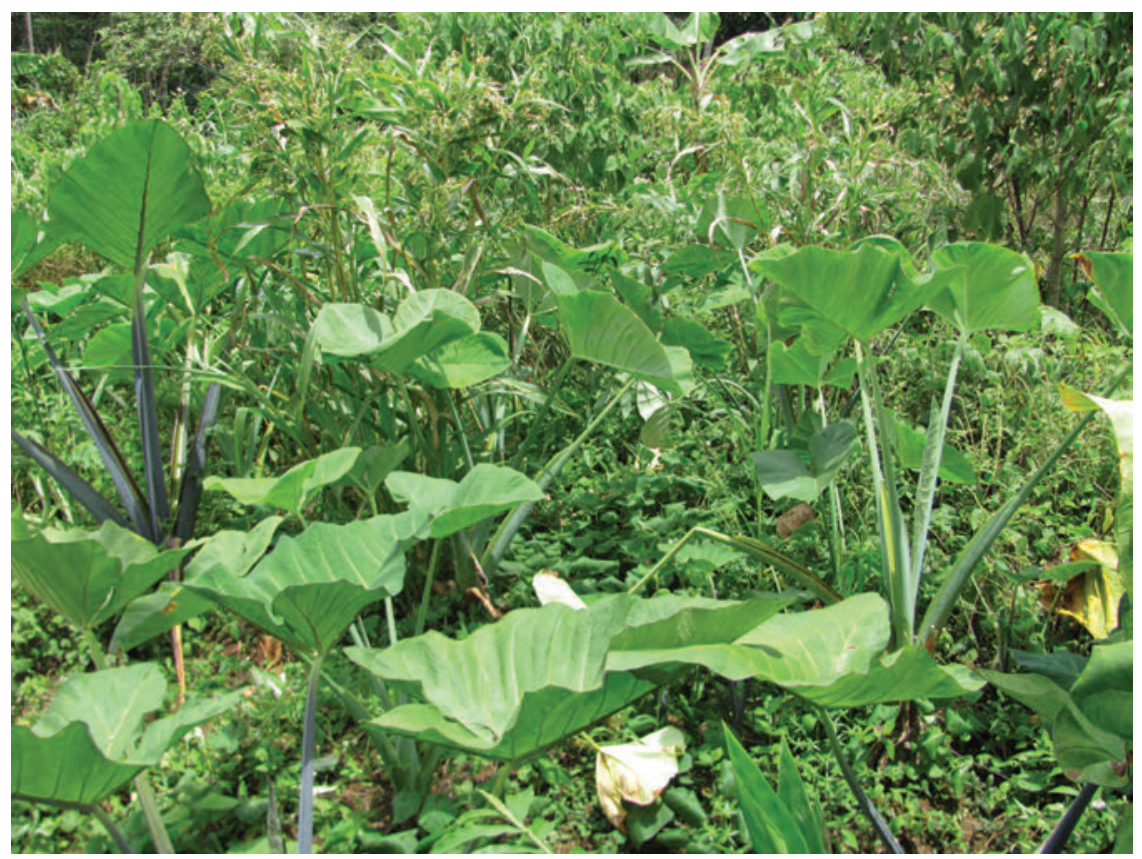

Figure 4. Living in the midst of "animal fodder.” Photo by Kristina Lyons.

Only after knotty bundles of diverse roots and organisms had, as Elva explained, "created a climate" was it acceptable for human hands to loosen up and turn the insides of soils out, allowing for the aeration that invites life and death - digestion, defecation, and decomposition - to proliferate. Later on they began to plant human food crops, most of which were noncommercial (or at least nontraditionally commercial) perennial varieties that do not require replanting after each harvest, purchased seeds, chemical inputs, or daily upkeep: for example, Amazonian wheat, medicinal plants, star nut, plantains, tubers, fruits, and greens for the hens, ducks, rabbits, and guinea pigs that provide manure for the farm (and that are also easily stolen by petty thieves). Nelso and Elva's children did not show initial interest in farming, and instead took minimum-wage jobs in town to support their 
own growing nuclear families. However, they continued to share the same house and eat from the gardens. Over time, they watched the farm convert into a dynamic space frequented by other farmers interested in trading seeds, produce, and recipes, and also town folks who came to buy fruits, vegetables, and medicinal plants unavailable at commercial markets in Mocoa. Elva now specializes in preparing more than three hundred Amazonian recipes that she shares with other women, especially those of Mocoa's network of displaced rural families who have lost their land, their food security, and their food autonomy.

\section{DYING DECOMPOSITIONALLY: Creating Conditions and Living en}

\section{Medio del Rastrojo}

The different waves of structural and armed violence in the late-nineteenth and twentieth centuries that expelled families from the country's fertile Andean regions into frontier territories impacted by extractive economies, "poor" soils, and armed conflict necessarily transformed biopolitically informed attachments to life. For example, Nelso and Elva seek to create conditions to combat displacement in a context of ongoing uncertainty by working toward a future they may never see. They partake in material practices in the present that are overly inhabited by a future territory that does not yet exist, but that strives to materialize its collective affordances and capacities (for example, in grassroots struggles to fund PLADIA and transform the state's rural development model, and in everyday practices through which people attempt to figure something out without abandoning their farms). At the same time, a past territory can never be fully eradicated because it remains present in different modes of cultivating, and in the recovery of recipes, medicines, and seeds. In this way, the cultivation of a farm or garden strives to farm itself as a community of future human and nonhuman cultivators. ${ }^{15}$ The network of farmers I accompanied engages in a recursive balance between creative innovation and the recovery of diverse popular, traditional, and ancestral practices. For example, they combine popular processes to low-tech their farms with elements from specific sciences they consider subversive, such as agroecology and soil microbiology, without granting science a unique authority over indigenous and popular knowledges and experimental practices.

There is no singular story to tell about how these farmers come to engage in selva practices. They read agroecology pamphlets and remember practices their grandparents and indigenous neighbors performed. They exchange experiences and seeds with other small-farming families. They take long walks in the forest to study plants and trees. Some have read Marx. Others explain that they are "apprentices of the selva" and have learned to cultivate ojos para ella (eyes for her 
[la selva]) (Lyons 2014). Farmers engaged in these selva life processes are becoming what Heraldo calls "Amazonian men and women" (Vallejo 1993). I argue this is less an environmental subjectivity than an ongoing relationality: learning to cultivate new modes of eating, walking, seeing, tasting, exchanging, growing, and inhabiting the Andean-Amazonian foothills that do not rely on the idea of a human who is somehow separate from and master over a selvatic nature. Heraldo contrasts Amazonian men and women with lideres sociales (social leaders) who constitute a newly organized generation of activists leading protests, denouncing human rights violations, and negotiating with government officials to demand the recognition of rural communities as legitimate political interlocutors. If they have time to carry on farming, many of these social leaders continue to be cocaleros, or have replaced coca with other monocrops such as pineapple, which has the ability to resist the acidity left behind by intensive coca production in naturally acidic soils. While they stand in solidarity with these social leaders and the ideological struggles they represent and provide regional social organizations with the kind of alternative technical assistance I have mentioned, Amazonian men and women do not necessarily have the time or disposition to attend every protest, sit through bureaucratic meetings, or negotiate with elected officials. ${ }^{16}$ Their lives are deeply enmeshed with, and hence mutually obliged by, other beings and elements that share life and labor among gardens, orchards, and forests. The ecological temporalities of these kinds of relations are largely imperceptible within the official time of politics, such as government reports on competitive agricultural yields, the four-year development plans that accompany elected officials or news reports on popular uprisings.

After being violently dispossessed of five farms during the past twenty-five years, Heraldo now lives fifteen minutes down the road from Nelso and Elva. When we received news that his neighbor was gunned down at dawn, he explained to me: "I can die, but the farms will remain." He was not referring to the desire to demarcate private property inhabited by a self-interested household, deforested fields, and ordered rows of commercial crops. These kinds of farms that fall in line with conventional state-based forms of property acquisition can easily slip away, working against the continuation of rural life in the territory. Instead, he referred to cultivating conditions for life by "recolonizing the farm with selva." This recolonization of farms with forest materially and conceptually disrupts notions of private property. Farms are never only farms when they are also always regional watersheds, foothills, forests, biological corridors, and floodplains. It is farms as more than farms that multiplies what I have referred to as pulsations of 
cosustainability: the different birds and bees attracted to creeping plant gardens, the reawakening of microbial worlds as communities of plants return, the multiplication of diverse selva practices resonating throughout a territory in community seed banks, the bartering of food, the stimulation of small-farmer markets, the recovery of food autonomy, the multiplication of happiness one farm at a time, and the creation of conditions for the recycling of hojarasca itself. This layer of fallen and dying leaves eventually undergoes natural processes of decomposition, and when incorporated back into the germination of the earth, it is always already regenerative of selva life.

In an attempt to reflect carefully on the contingent potentiality of this kind of germinating withdrawal or decompositional mode of retreat, I take inspiration from discussions in feminist and disability studies (Davis 2013; Harrison 2008; Diprose 2002) on corporeal vulnerability, and such phenomena as susceptibility, indolence, and fatigue. Rather than conceive of these states as degraded ways of being in the world that must be set right or transcended by benevolent action, we can think of fatigue as an occurrence whose reality is made up of refusal or hesitancy. One of the most poignant lessons Nelso, Elva, Heraldo, and other farmers shared with me is that the region's soils - and by soils they were never referring to a stable entity, but to continuous relations of composure and decomposing that in fleeting, massifying moments produces a natural body scientists call "soil”_ could never be colonized, but only destroyed. Amazonian soils could not be tamed by human-led productive fantasies, but they could be used up and abandoned. Furthermore, through this seeming destruction a vocation to live might resist violent modes of death by becoming into it, which is not necessarily death or dying, but a melding back into a transformative fatigue.

According to Nelso, what many agronomists and farmers describe as the "limiting fragility" of Amazonian soils is actually a mode of resistance that might allow — indeed oblige - farmers to slow down as well. It is not soils' intentional refusal in the same way that they express their own growing recalcitrance before the commodified notion of life underpinning growth-oriented economic imperatives. Rather, it may be an expression of a capacity for weariness and recoil from the impossibility of existing under the relentless strain of extractive conditions that exceed the soil's abilities to absorb, repose, and transform. Thus what appears dead is not; rather, for Nelso, this transformational period marks the soil's imperceptible and regenerative unworking and reworking. The reworking evades not only its own exploitation but also a continuum of exploitation linking farmers, microbes, plants, seeds, soils, and trees. Not simply a mechanical cause-and-effect 
interaction or biological breakdown, but the sheer physical force of fragility, the feeding loop of activity and withdrawal characterizing an ecological relationality. Relatedly, Heraldo and Nelso argue that when technicians and bureaucrats claim that one cannot sustain a productive agricultural livelihood in the Amazon, they are really suggesting that one cannot sustain a colonizing, extractive, and neoliberal agricultural livelihood.

In this article, I have not tried to tell a triumphant tale of small-scale agroecological farming as an improved agricultural model that should be singularly adopted throughout Colombia's western Amazon. Nor do I want to argue that technical decisions over crop choice and livelihood are always or simply a political choice. Rather, I have highlighted the built-in expectation of vulnerability present in an ecological sense of being in the world: farmers' necessary acceptance of decay, looping back to begin again, a cautionary lying low and a decompositional mode of regeneration. They remind us that transformative potentiality is not a human privilege, but rather a relational matter dispersed in the connections and labor among people as well as other kinds of beings and things. They urge us to take seriously the ways different human and nonhuman relations afford differential political and economic capacities. At stake in these farmers' struggle is not the right to idleness, but the right to another kind of work, another kind of dream, and a world that does not run only on the inevitable and structurally designed market-based time and velocity. What may be most inspiring is how their selva practices slow down the power of dominant reasoning: for example, planting "weeds," living "in the midst of animal fodder," preferring not to correct or resuscitate "poor soils," and rejecting the salvation offered by the eradication of illicit crops. Much as the feminist philosopher of science Isabelle Stengers (2005) does, their practices demand that we slow down the power of reasoning imbued in our own concepts to create a space for hesitation. This hesitation obliges us to ask what we claim to know when we say that we are constructing a good or common world, and how this knowledge comes to justify war while rendering unimaginable other kinds of political thought and action.

In the Andean-Amazonian foothills of Colombia a growing number of rural communities argue that there is something more important at stake than uprooting illicit crops or biopolitically improving the productive capacities of soils and souls, something more vital than producing enough exportable commodities to feed a far-off world whose moral standing is protected by continued assaults against the worlds that these farmers strive to build. They suggest that the wrong kinds of questions are being asked. Perhaps it is not a question of becoming better-more 
productive farmers, more legal and more responsible citizens, or more efficient capitalists. It is necessary to slow down and ask what kinds of questions emerge from an ecologically relational world that not only obliges different strategies for how to keep on enduring in the face of a war machine that proposes peace through poison, but that is also striving to cultivate a different socioecological, economic, and political reality. These struggles in southern Colombia articulate with larger contemporary political processes in the global North and South, including antiextractivism, anticapitalism, degrowth, and - throughout the Andes-heterogeneous practices of buen vivir (living well) that reject human-centered notions of growth and productivity tied to a universal vivir mejor (living better) (D'Alisa, DeMaria, and Kallis 2015; Gudynas and Acosta 2011). Living well is, of course, never separate from the question of the right to die well — of the right to modes of dying in which death is allowed to decompose into life, rather than being violently ripped from place, territory, soil, selva, and home. This is a death that decomposes into life, just as leaves spill from branch to ground, turn over and slowly rot to germinate from a pulsating layer of hojarasca again.

\section{ABSTRACT}

How is life in a criminalized ecology in the Andean-Amazonian foothills of southwestern Colombia? In what way does antinarcotics policy that aims to eradicate la mata que mata (the plant that kills) pursue peace through poison? Relatedly, how do people keep on cultivating a garden, caring for forest, or growing food when at any moment a crop-duster plane may pass overhead, indiscriminately spraying herbicides over entire landscapes? Since 2000, the U.S.-Colombian War on Drugs has relied on the militarized aerial fumigation of coca plants, coupled with alternative development interventions that aim to forcibly eradicate illicit livelihoods. Through ethnographic engagement with small farmers in the frontier department of Putumayo, the gateway to the country's Amazon and a region that has been the focus of counternarcotic operations, this article explores the different possibilities and foreclosures for life and death that emerge in a tropical forest ecology under military duress. By following farmers, their material practices, and their life philosophies, I trace the ways in which human-soil relations come to potentiate forms of resistance to the violence and criminalization produced by militarized, growth-oriented development. Rather than productivity - one of the central elements of modern capitalist growththe regenerative capacity of these ecologies relies on organic decay, impermanence, decomposition, and even fragility that complicates modernist bifurcations of living and dying, allowing, I argue, for ecological imaginaries and life processes that do not rely on productivity or growth to strive into existence. [violence; development; small farmers; soil; decomposition; War on Drugs; Colombian Amazon] 


\section{NOTES}

Acknowledgments This article would not have been possible without the ongoing friendship of Heraldo Vallejo, Nelso Enríquez, María Elva Montenegro, and members of the Mesa Regional de Organizaciones Sociales del Putumayo, Baja Bota Caucana y Cofanía, Jardines de Sucumbíos, Nariño, among innumerable others in Colombia with whom I have learned to think and live. I am also very grateful for the careful readings that versions of this article received from Marisol de la Cadena, Andrew Mathews, Tanya Richardson, Jake Culbertson, Morten Pedersen, Brent Crosson, and Iván Vargas, as well as three anonymous readers. I received invaluable feedback from audiences at the Ethnographic Engagements workshop at the University of California, Santa Cruz, the Feminist Studies Department at the University of California, Santa Cruz, the Center for Studies on Political Ecology in Bogotá, and the biennial meeting of the Society for Cultural Anthropology - in particular, from Karen Barad, Donna Haraway, Mark Anderson, Don Brenneis, Judith Farquhar, Diana Ojeda, and Diana Bocarejo. My research was funded by the Wenner-Gren Foundation, the Social Science Research Council, and the University of California Pacific Rim Research Program.

1. With roots in the 1980 s, the AUC grew to about twenty thousand members, and was heavily financed through the drug trade, local landowners, cattle ranchers, mining and oil companies, agroindustry, and Colombia's traditional political class.

2. Glyphosate, which Monsanto packages as Roundup Ultra, has been used to spray illicit crops in Colombia since 1986. The quantity of glyphosate used in fumigation operations was estimated to be $110 \%$ more concentrated than the commercially available version. Glyphosate was mixed with polyethoxylated tallow amine (POEA) and an additional surfactant, Cosmo Flux 411F, to make the herbicide stick to plants in humid tropical climates (Vargas Meza 1999).

3. The Antinarcotics Directorate of the National Police provided these official statistics on August 18, 2015.

4. Between 2000 and 2002, controversial debates over whether to introduce biological agents into coca eradication strategies resurfaced in the U.S. Congress, the European Parliament, and the Colombian Ministry of the Environment. While the U.S. government affirmed that it would only support biological eradication research in Colombia through a multilateral mechanism, rural communities claim that covert experiments have occurred.

5. In interviews, USAID employees explained more than a decade and $\$ 80$ million of failed development projects in Putumayo in terms of an "unfortunate, but instructive learning curve." The cost of production in remote areas was much higher than anticipated; market studies were not conducted to ensure a niche for newly introduced agroindustrial products; offering aid only to coca-growing families stimulated the planting of coca and failed to help individuals who did not grow coca, but were employed within its broader commodity chain; market-oriented crops were plagued by problems of "quality control" (that is, rampant fungus and tropical pests).

6. In "Society Must Be Defended," Michel Foucault (2003) outlined the complex entanglements of the sovereign, disciplinary, and biopolitical forms of power at play in the machinery of Nazi genocide. Achille Mbembe (2003) then situated this industrialized European savagery within a history of African colonization, where colonists experimented with the spectacular display of irrational and excessive killing.

7. There are nine indigenous peoples that currently inhabit Putumayo, five of which are original to the territory. Margarita Chaves (2005) elucidates the everyday interactions, shifting identifications, and political alliances between indigenous communities and small farmers in Putumayo, despite classic representations of their supposed isolation and conflicting forms of conviviality.

8. Colombia is currently the second-most unequal country in the world. Despite its reputation as one of Latin America's most stable democracies, the state has never experienced a period of full labor incorporation, widespread land reform, or a true populist 
phase. Its democracy has traditionally been described as restrictive, elite, and violent (Carroll 2011).

9. Since October 2012, the FARC-EP and the Colombian government have been engaged in what is now the country's fourth national peace process. Colombia's second-largest guerrilla group, the National Liberal Army, has expressed interest in entering into a similar negotiation process.

10. Constitutional reforms since 2004 have steadily declared a variety of food production, commercialization, and seed-propagating practices used by small farmers to be illegal. For more information, see www.semillas.org.co.

11. The Regional Working Group of Social Organizations is an umbrella network of rural social organizations that has inherited a history of political protest and organizational work on the part of rural laborers and farmers, workers in the oil industry, civic organizations, indigenous and Afro-Colombian communities, and youth and women's organizations dating back to the 1970s. Some 80 percent of organizations that belong to the Regional Working Group are campesina. The Environmental Clinic is an initiative supported by the Quito-based NGO Acción Ecológica.

12. After the Marchas Cocaleras, right-wing paramilitary organizations occupied the majority of towns in Putumayo and persecuted community leaders. This forced the majority of rural social movements to suspend their organizational activities for almost a decade between 1996 and 2006. PLADIA is the current version of the community-based development plan that was proposed during strike negotiations in 1996. Despite verbal and written accords, the implementation of PLADIA has yet to be funded at the municipal, state, or national level.

13. For more on the relationship between government forces and paramilitaries, the role of FARC-EP with respect to the profitability of drug trafficking, and local results of the demobilization of the AUC, see Jansson 2008.

14. The dominant scientific representation of Amazonian soils is that they are "senile" (León 1999). That is, they are inhospitable to conventional market-driven agriculture without heavy corrective measures, such as lime, fertilizer, and other chemical inputs. For insight into soil scientists' stakes in these debates and their growing dissatisfaction with the modern soil classification systems they institutionalized in Colombia in the 1970s, see Lyons 2014.

15. I am indebted to Alberto Corsín Jiménez's (2013) discussion of the urban cultivation table produced in Handmade Urbanism workshops in Madrid, as a means of imagining how a city or territory may jump ahead of itself.

16. The Regional Working Group of Social Organizations has come to reject what Winifred Tate (2013) calls "proxy citizenship" by distancing itself from NGOs that interfere with their ability to make direct claims for redress from the state.

\section{REFERENCES}

Aguilar, J.C.

1999 Evangélico y colonización: Una aproximación a la historia del Putumayo desde la época prehispánica a la colonización agropecuaria. Bogotá: Ecoe Editores.

Allison, Anne

2013 Precarious Japan. Durham, N.C.: Duke University Press.

Ariza, Eduardo, María Clemencia Ramírez, and Leonardo Vega

1998 Atlas cultural de la Amazonia Colombiana: La construcción del territorio en el siglo XX. Bogotá: ICANH.

Barad, Karen

2007 Meeting the Universe Halfway: Quantum Physics and the Entanglement of Matter and Meaning. Durham, N.C.: Duke University Press.

Bebbington, Anthony and Jeffrey Bury, eds.

2013 Subterranean Struggles: New Dynamics of Mining, Oil, and Gas in Latin America. Austin: University of Texas Press. 
Beittel, June S.

2012 "Colombia: Background, U.S. Relations, and Congressional Interest." Congressional Research Service, RL32250. https://www.fas.org/sgp/crs/ row/RL32250.pdf.

Biehl, João

2005 Vita: Life in a Zone of Social Abandonment. Berkeley: University of California Press.

Calle, Maria Clara

2014 “Putumayo está en crisis.” Semana, August 30. http://www.semana.com/ nacion/multimedia/putumayo-tendra-paro-campesino-por-petroleo-coca/ 400937-3.

Carroll, Leah Anne

2011 Violent Democratization: Social Movements, Elites, and Politics in Colombia's Rural War Zones, 1984-2008. Notre Dame, Ind.: University of Notre Dame Press.

Chaves, Margarita

2005 "Qué va a pasar con los indios cuando todos seamos indios? Ethnic Rights and Reindianization in Southwestern Colombian Amazonia.” $\mathrm{PhD}$ dissertation, University of Illinois at Urbana-Champaign.

Corsín Jiménez, Alberto

2013 “Three Traps Many." Paper presented at the John E. Sawyer Seminar "Indigenous Cosmopolitics: Dialogues about the Reconstitution of Worlds," University of California, Davis, March 18.

D’Alisa, Giacomo, Frederico DeMaria, and Giorgos Kallis

2015 Degrowth: A Vocabulary For a New Era. London: Routledge.

Das, Veena

2006 Life and Words: Violence and Descent into the Ordinary. Berkeley: University of California Press.

Davis, Lennard J., ed.

2013 The Disability Studies Reader. 4th edition. New York: Routledge.

de la Cadena, Marisol

2010 "Indigenous Cosmopolitics in the Andes: Conceptual Reflections beyond 'Politics." Cultural Anthropology 25, no. 2: 334-70. http://dx.doi.org/ 10.1111/j.1548-1360.2010.01061.x.

Departamento Nacional de Planeación de Colombia

2010 "Plan nacional de desarrollo, 2010-2014: prosperidad para todos.” Bogotá. https: / /www.dnp.gov.co/Plan-Nacional-de-Desarrollo/PND-2010-2014/

Diprose, Rosalyn Paginas/Plan-Nacional-De-2010-2014.aspx.

2002 Corporeal Generosity: On Giving with Nietzsche, Merleau-Ponty, and Levinas. Albany: State University of New York Press.

Escobar, Arturo

2011 Encountering Development: The Making and Unmaking of the Third World. Princeton, N.J.: Princeton Universty Press.

2014 Sentipensar con la tierra: Nuevas lecturas sobre desarrollo, territorio y diferencia. Medellín, Colombia: UNALUA.

Foucault, Michel

2003 "Society Must Be Defended": Lectures at the Collège of France, 1975-1976. Translated by David Macey. London: Picador.

Gibson-Graham, J. K.

2006 The End of Capitalism (As We Knew It): A Feminist Critique of Political Economy.

Gudynas, Eduardo Minneapolis: University of Minnesota Press.

2014 "Sustentación, aceptación y legitimación de los extractivismos: múltiples expresiones pero un mismo basamento." OPERA 14: 137-59. http:// revistas.uexternado.edu.co/index.php/opera/article/view/3844/4155. 
Gudynas, Eduardo, and Alberto Acosta

2011 "El buen vivir más allá que el desarrollo." Quehacer 181: 70-81. http://www. desco.org.pe/node/6808.

Haraway, Donna

2008 When Species Meet. Minneapolis: University of Minnesota Press.

Harrison, Paul

2008 "Corporeal Remains: Vulnerability, Proximity, and Living On after the End of the World.” Environment and Planning A 40, no. 2: 423-45. http://dx.doi.org/ $10.1068 / a 391$.

Jansson, Oscar

2008 "The Cursed Leaf: An Anthropology of the Political Economy of Cocaine

León, Tomás Production in Southern Colombia.” PhD dissertation, Uppsala University.

1999 "Perspectivas de la investigación en los suelos de la Amazonia." In Amazonia colombiana: diversidad y conflicto, edited by German I. Andrade, Adriana Hurtado, and Ricardo Torres, 237-55. Bogotá: AGORA.

Lyons, Kristina Marie

2014 "Soil Science, Development and the 'Elusive Nature' of Colombia's Amazonian Plains." Journal of Latin American and Caribbean Anthropology 19, no. 2: 212-36. http://dx.doi.org/10.1111/jlca.12097.

Mbembe, Achille

2003 “Necropolitics." Translated by Libby Meintjes. Public Culture 15, no. 1: 11-40. http://dx.doi.org/10.1215/08992363-15-1-11.

Mesa Regional de Organizaciones Sociales del Putumayo, Baja Bota Caucana y Cofanía, Jardines de Sucumbíos

2015 Putumayo: sembrando vida y construyendo identidad. Historia de la Mesa Regional Mol, Annemarie (2006-2014). Bogotá: Corcas Editores SAS.

2008 "I Eat an Apple. On Theorizing Subjectivities." Subjectivity 22: 28-37. http:// dx.doi.org/10.1057/sub.2008.2.

Nouvet, Elysée

2014 "Some Carry on, Some Stay in Bed: (In)convenient Affects and Agency in Neoliberal Nicaragua." Cultural Anthropology 29, no. 1: 80-102. http://dx.doi.

Paley, Dawn org/10.14506/ca29.1.06.

2014 Drug War Capitalism. Oakland, Calif.: AK Press.

Papadopoulos, Dimitris, Niamh Stephenson, and Vassilis Tsianos

2008 Escape Routes: Control and Subversion in the Twenty-First Century. London: Pluto Press.

Povinelli, Elizabeth A.

2011a Economies of Abandonment: Social Belonging and Endurance in Late Liberalism. Durham, N.C.: Duke University Press.

2011b "Woman on the Other Side of the Wall: Archiving the Otherwise in Postcolonial Digital Archive." differences: A Journal of Feminist Cultural Studies 22, no. 1: 14671. http://dx.doi.org/10.1215/10407391-1218274.

2011c “Routes/Worlds.” e-flux, no. 27. http://www.e-flux.com/journal/ routesworlds/.

2014 "Holding Up the World, Part III: In the Event of Precarity . . A Conversation." e-flux, no. 58. http://www.e-flux.com/journal/holding-up-the-world-part-iiiin-the-event-of-precarity-...-a-conversation-between-elizabeth-povinelli-andlauren-berlant/.

Puig de la Bellacasa, María

2013 "Encountering Bioinfrastructure: Ecological Struggles and the Sciences of Soil." Social Epistemology: A Journal of Knowledge, Culture and Policy 28, no. 1: 26-40. http://dx.doi.org/10.1080/02691728.2013.862879.

Ramírez, María Clemencia

2001 Entre el estado y la guerrilla: identidad y ciudadanía en el movimiento de los campesinos cocaleros del Putumayo. Bogotá: ICANH. 
Stengers, Isabelle

2005 “The Cosmopolitical Proposal.” In Making Things Public: Atmospheres of Democracy, edited by Bruno Latour and Peter Weibel, 994-1003. Cambridge, Mass.: MIT Press.

2010 “Including Nonhumans in Political Theory: Opening Pandora's Box.” In Political Matter: Technoscience, Democracy and Public Life, edited by Bruce Braun and Sarah Stevenson, Lisa J. Whatmore, 3-34. Minneapolis: University of Minnesota Press.

2014 Life Beside Itself: Imagining Care In The Canadian Arctic. Berkeley: University of California Press.

Stewart, Kathleen

2007 Ordinary Affects. Durham, N.C.: Duke University Press.

Tate, Winifred

2013 "Proxy Citizenship and Transnational Advocacy: Colombian Activists from Putumayo to Washington, DC.” American Ethnologist 40, no. 1: 55-70. http://

Taussig, Michael dx.doi.org/10.1111/amet.12005.

1984 Shamanism, Colonialism, and the Wild Man: A Study in Terror and Healing. Chicago:

Tsing, Anna University of Chicago Press.

2011 “Arts of Inclusion, or, How to Love a Mushroom.” Australian Humanities Review, no. 50. http://www.australianhumanitiesreview.org/archive/Issue-May-2011/ tsing.html.

United Nations Office on Drugs and Crime (UNODC)

2005 "Colombia: Coca Cultivation Survey for 2004." https://www.unodc.org/ unodc/en/crop-monitoring/?tag=Colombia.

2015 “Colombia: Monitoreo de Cultivos de Coca 2014." https://www.unodc.org/ unodc/en/crop-monitoring/?tag=Colombia.

Vallejo, Heraldo

1993 "El nuevo hombre amazónico: Una visión de desarrollo para el departamento del Putumayo." Putumayo: Expresión de Identidad Regional 1: 8-25.

Vargas Meza, Ricardo

1999 Fumigación y conflicto: Políticas antidrogas y deslegitimación del estado en Colombia. Bogotá: TNI/Acción Andina.

Veltmeyer, Henry, and James Petras

2014 The New Extractivism: A Post-Neoliberal Development Model or Imperalism of the TwentyFirst Century? London: Zed Books.

Verran, Helen

2002 "A Postcolonial Moment in Science Studies: Alternative Firing Regimes of Environmental Scientists and Aboriginal Landowners." Social Studies of Science 32, Zeiderman, Austin nos. 5-6: 729-67. http://dx.doi.org/10.1177/030631270203200506.

2013 "Living Dangerously: Biopolitics and Urban Citizenship in Bogotá, Colombia." American Ethnologist 40, no. 1: 71-87. http://dx.doi.org/10.1111/amet.12006. 